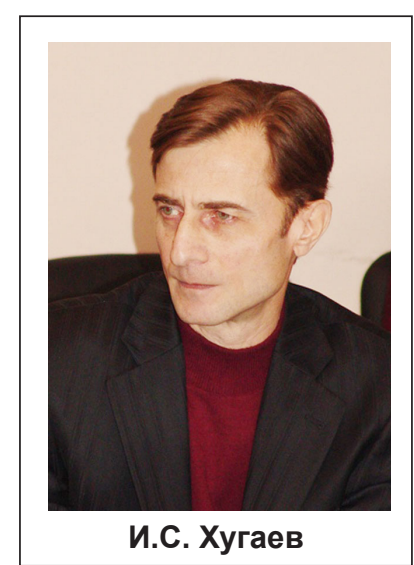

\section{1. ИНТЕРЕСНАЯ РАБОТА}

Что такое власть? Какова природа власти? Верно ли воображал ее себе Вовка в Тридевятом царстве: «Хочешь - мороженое, хочешь пирожное»?..

Власть часто понимают как свободу. Действительно, эти понятия тесно связаны. Но разве можно сказать, что царь - свободен? Отчего же он тогда, услышав Вовку, не продолжил спокойно красить забор, а в ужасе бросился к своему трону?

На поверку выходит, что чем выше стоит человек на общественной лестнице, тем меньше у него свободы. Свобода - как кислород, которого тем меньше, чем выше ты поднимаешься в гору. Лев Толстой писал: ««Самая сильная, неразрываемая, тяжелая и постоянная связь с другими людьми есть так называемая власть над другими людьми, которая в своем истинном значении есть только наибольшая зависимость от них».

Таким образом, самый свободный человек в обществе - не царь, а нищий бродяга, не президент, а бомж. «Богатые тоже плачут»? - Богатые особенно плачут.

Но абсолютной свободы нет, конечно, и у бомжа. Абсолютная свобода и жизнь несовместимы. Абсолютно свободны только покойники. Вот чего ищут в смерти те, кто отчаялся в жизни...

Итак, Вовка понимает власть как волю, а царь понимает власть как долг. В этом-то понятии и заключается основное содержание всякой власти. Власть - не воля и право, а долг и обязанность.

Один новоиспеченный президент, когда его спросили, как он чувствует себя в новой должности, ответил не думая: «Интересная работа». За такие слова Думе следовало бы сразу инициировать процедуру импичмента. Потому что это никакая не работа (и уж менее всего интересная; интересная работа у страхового агента и дизайнера дачных участков), а крест.
УДК 82-4

\section{БОРОДАТЫЙ АНЕКДОТ \\ И.С. Хугаев"}

Но импичмента не последовало, и несколько позже этот президент был замечен на дискотеке. Естественно: ведь если это работа (пусть даже самая интересная), то от нее следует иногда отдыхать.

Открытость, гуманность, демократичность это все самые современные требования ко всякой легитимной власти, и оспаривать их правомерность неразумно, если только мы не хотим прослыть ретроградами. Но, с другой стороны, так ли уж это хорошо, если царь красит заборы, а президент танцует на дискотеке (дело прошлое, конечно), причем танцует безнадежно плохо, и в его свите нет ни одного человека, который бы ему шепнул об этом на ухо?.. То есть, если он танцует, значит, он открыт; но если он открыт, то почему нельзя ему сказать, чтобы он не танцевал?.

\section{2. ИДЕЯ ФИКС ГЕРОЯ}

«Этот скверный анекдот случился именно в то самое время, когда началось с такою неудержимою силою и с таким трогательно-наивным порывом возрождение нашего любезного отечества и стремление всех доблестных сынов его к новым судьбам и надеждам».

Так начинается рассказ Ф.М. Достоевского «Скверный анекдот», который написан в 1862 году, и уже самое его вступление и заголовок заставляют современника отнестись к нему с полной серьезностью. Во-первых, современник любит анекдоты, особенно скверные, во-вторых, он тоже, как его предок в эпоху ресрорм XIX века, чувствует «порыв возрождения» и переживает «новые надежды».

Герой рассказа, генерал штатской службы Иван Ильич Пралинский, вполне еще молодой человек, как раз полон благородных идеалистических порывов, честолюбив, гордится тем, что слывет либералом, и считает своих начальни- 
ков, людей более опытных, «ретроградами». Главной его мыслью (у всех героев Достоевского есть своя идея фикс) выступает мысль о гуманности как главном ключе к реформе, прогрессу и возрождению: «Гуманность первое дело, гуманность с подчиненными, памятуя, что и они человеки».

Ничего, что генерал немного «под шафе»; мысль прекрасная, и вся духовная, поэтическая и философская история человечества тому порука. И сердце читателя, как и самого автора, безусловно, на стороне г. Пралинского, а не его скептических собеседников. Но всякая «осанна», как говорил Достоевский, должна пройти через «горнило сомнений», и теперь, очевидно, этому убеждению Ивана Ильича суждено, по всем законам литературы, пройти проверку самой практической жизнью.

\section{3. СОБЛАЗН}

Генеральский чин Пралинского и орден на шее нужны как атрибуты и символы власти и положения, чтобы проблема произведения была прорисована четко и хорошо читалась, а композиция «анекдота», как мы сейчас убедимся, подчинена указанной выше задаче: посмотреть, как работает теория г. Пралинского на практике. Ведь он тоже, в известном смысле, отправился на дискотеку. Но все по порядку.

Итак, выйдя поздно ночью из гостей, где он и блеснул своей гуманистической тирадой, генерал вдруг обнаруживает, что его человека и кареты нет на месте. Проклиная Трифона в выражениях, которые уже плохо согласуются с его гуманными претензиями («мерзавец!», «подлец народ!»), он отправляется домой пешком.

Прогулка морозной зимней ночью подействовала на него целительно. «Ему становилось как-то особенно приятно. К тому же люди под хмельком быстро меняют впечатления. Ему даже начали нравиться невзрачные деревянные домики пустынной улицы...»

В одном из таких домиков Иван Ильич услышал вдруг звуки музыки и буйного веселья и осведомился у подвернувшегося кстати городового о причине такого шабаша. Оказалось, что здесь играет свадьбу его подчиненный по службе, регистратор Порфирий Пселдонимов.

Тут-то и соблазняется г. Пралинский идеей показать себе и миру, какова его теория в действии: «Что же!.. вот мы все говорим, говорим, а коснется до дела, и только шиш выходит. Bom пример, хоть бы этот самый Пселдонимов... Что бы с ним было, если б я теперь же вдруг взял и вошел? (...) Да-с. Мы все кричим о гуманности, но героизма, подвига мы сделать не в состоянии (...) Ну, что может быть про- ще, изящнее такого поступка! (...) Да знаете ли вы, что Пселдонимов будет детям своим поминать, как сам генерал пировал и даже пил на его свадьбе! Да ведь я униженного нравственно подыму, я самому себе его возвращу... Ведь он десять рублей в месяц жалованья получает!..»

И генерал отважно направился к домику своего подчиненного.

\section{4. ТРИ ПРЕДУПРЕЖДЕНИЯ}

Мы все - пророки и ясновидящие: провидение говорит с каждым из нас и делает нужные подсказки. Сложность состоит в том, что это язык не вербализованный; он сводится к знакам, которые мы не замечаем, или, заметив которые, не придаем им, однако, значения, как пустым случайностям и совпадениям. Но случай - это и есть божественный язык. Сколько раз каждый из нас имел возможность убедиться, что в той или иной ситуации нам были скрытые знамения, предостерегающие от тех или иных решений. К сожалению, для большинства смысл божественных намеков открывается тогда, когда бывает уже слишком поздно.

Едва генерал вошел в сени, как прозвенел ему первый звоночек: «Туm хоть и горел где-то в углу сальный огарок (...), но это не помешало Ивану Ильичу... попасть левой ногой в галантир, выставленный для остужения (галантир - холодное заливное из рыбы, мяса или дичи. - И.Х.). (...) Раздавленный галантир его было сконфузил, и на одно самое маленькое мәновение у него промелькнула мысль: не улизнуть ли сейчас же? Но он почел это слишком низким».

А скоро и второй звонок прозвенел - а сразу за ним и третий: едва он вошел в комнату к танцующим, где стояло какое-то бешеное веселье, «мелькнул светло-голубой шарф какой-то дамы, задевший его по носу. За ней в бешеном восторге промчался медицинский студент с разметанными вихрем волосами и сильно толкнул его по дороге».

Словно само провидение гонит его вон из этого дома - а он как глухой, который пучит глаза и не понимает, чего от него хотят. Ведь, по большому счету, еще и теперь генералу не поздно «улизнуть», поскольку его еще не заметили.

\section{5. ЭМАНЦИПАЦИЯ}

Что ж? - если мы не понимаем увещеваний, судьба берет в руки розги. Все пошло не так, как он рисовал себе, предаваясь тщеславным мечтаньям, стоя перед злополучным домом регистратора Пселдонимова. Поначалу он действительно, как и ожидал, всех сконфузил и смутил своим явлением, своим «гарун аль-рашидским 
нашествием» и поверг в столбняк самого виновника торжества, и его усадили на диван и подвинули к нему стол, который был до того отставлен для танцев, но скоро положение начало выходить из-под контроля.

Пока он рассказывал, стараясь быть непринужденным (уже это давалось ему не так легко, как он воображал), историю со своим нерадивым Трифоном и невольной пешей прогулкой, которая его и привела в дом Пселдонимова, общество вышло из состояния почтительного оцепенения, «а только все были дики и почти все про себя враждебно смотрели на персону, ввалившуюся к ним, чтоб нарушить их веселье».

Уйти вовремя генералу Пралинскому не удалось (он думал уйти победителем сердец еще до торжественного ужина, благословив молодых и пообещав прийти в следующий раз через девять месяцев, «хе-хе!»); не удалось именно потому, что он еще не преуспел, как надеялся, во всем неотразимом блеске обозначить «нравственную цель» своего визита. Иван Ильич «терялся, он чувствовал, что ему... ужасно неловко... что почва ускользает из-под его ног, что он куда-то зашел и не может выйти, точно в потемках». Поэтому, когда перед ним поставили бутылку шампанского, он увидел в ней средство хоть както скрыть неловкость положения: «Он прихлебнул, и все-таки оно показалось лучше, чем такто сидеть. « - ...Но я надеюсь, - замечает Иван Ильич, - вы поймете, зачем я здесь... Ведь не вино же в самом деле я пить пришел. Хе-хе!..»

Вскоре после того как он выпил здоровье молодых и с треском раздавил между пальцев грецкий орех («он уже решился быть до конца популярным») и пошутил с гостями на разные темы, «все переменилось, как волшебством; все успокоились и готовы были... визжать и плясать, как если бы неожиданного гостя совсем не было в комнате. Причиной тому был... слух, что гость-то, кажется, того... под шефре. И (...) стало вдруг необыкновенно свободно».

Естественно, чем свободней становилось общество, тем стесненней чувствовал себя генерал Пралинский. Он «все более и более впадал в раздумье и в какое-то коловращение идей; в рассеянности он неприметно, но поминутно прихлебывал из бокала. Аким Петрович momчас же и усерднейше ему подливал».

И вот уже «какое-то горькое сомнение начало закрадываться в его душу: конечно, он очень любил... непринужденность; он желал, он даже душевно звал ее, эту развязность, когда они все пятились, и вот теперь эта развязность уже стала выходить из границ... Как же это? То пятились, а тут вдруг так скоро эманципировались!»

Как будто нарочно для того, чтобы усугубить худшие тревоги Ивана Ильича, одна дама во время танца «зашпилила свое платье булавками, так что выходило, как будто она в панталонах», а проходивший мимо его стола студент, только что закончивший кадриль, в ответ на невольное замечание генерала «Славно, молодой человек, танцуете» - «круто повернулся к нему, скорчил какую-то гримасу и, приблизив свое лицо к его превосходительству на близкое до неприличия расстояние, во все горло прокричал петухом».

\section{6. РЕВОЛЮЦИЯ}

Следует заметить, что Иван Ильич Пралинский болезненно мнителен и самолюбив, к тому же ведь он совсем не глуп, хоть идеалист. Теперь представьте себе, как глубоко он переживает эту стремительную «эманципацию», эту череду более или менее откровенных, хоть в основном простосердечных, оскорблений и казусов.

Поэтому нет ничего удивительного в том, что, когда общество расселось за праздничным столом, генерал «протянул руку, сам налил огромную рюмку водки и выпил. Он никогда прежде не пил водки. Он чувствовал, что как будто катится с горы, летит... что надо бы удержаться, уцепиться за что-нибудь, но нет к тому никакой возможности».

Психологическая динамика Пралинского живописна и вместе с тем достоверна, как протокол. Когда человек оказывается в плачевном состоянии по воле случая или других людей - это полбеды; беда, если он сознает, что сам виноват; теперь его «сердце... ныло! оно просилось на волю, на воздух, на отдых. Он ведь знал, очень хорошо знал, что еще давно бы надо было уйти, и не только уйти, но даже спасаться. Что все это вдруг стало не тем, ну совершенно не так обернулось, как мечталось давеча...»

В самом деле: «Когда он входил, он, так сказать, простирал объятия всему человечеству и всем своим подчиненным; и вот не прошло какого-нибудь часу, и он, всеми болями своего сердиа, слышал и знал, что он ненавидит Пселдонимова, проклинает его, жену его и свадьбу его». Недаром говорят, что от любви до ненависти - один шаг.

Крайнее смятение чувств генерала Пралинского выражается в его нелепых и, главное, противоречивых действиях: «Я ведь зачем пришел? Я разве затем пришел, чтоб здесь есть и пить?» - спрашивал он себя, закусывая селедку». Или: «...Иван Ильич хоть и налил было себе, но не хотел пить, и вдруг выпил как-то совершенно нечаянно». Знает, что пить нельзя - и пьет; знает, что надо «бежать» - и сидит. Сплошной «бес противоречия».

Уйти он, конечно, не может главным образом потому, что еще не отыграл своей роли до самого 
занавеса, до желательного «патетического момента», подобающего его сану: «... Что скажут? Скажут, что я по неприличным местам таскаюсь... Нет, надо так уйти, чтоб они все поняли, зачем я приходил, надо нравственную цель обнаружить (...) Они даже не уважают меня... Они так развязны, как будто бесчувственные... Да, я давно подозревал все молодое поколение в бесчувственности! Надо остаться во что бы то ни стало!.. (...) Заговорю о вопросах, о рефрормах, о величии России... я их еще увлеку! Да! Может быть, еще совершенно ничего не потеряно... Я вижу, они там пересмеиваются... Уж не надо мной ли, господи боже!». Поток сознания Ивана Ильича заслуживает особого внимания как поток, помимо прочего, пьяный; прецедентов в русской литературе, пожалуй, и нет.

Глубокий и невыносимый стыд, ненависть к окружающим и бессилие изменить развитие «сюжета» закономерно приводят к тому, что генерал Пралинский испытывает приступы хоть и понятной, но все же мелочной, малодушной паранойи; он уже уверен, что кругом враги, и все они в заговоре между собою. Ведь не случайно же в него бросаются хлебными шариками!

Заметим между прочим, что алкоголь в сюжете Достоевского несет вспомогательную функцию; это вовсе не причина происходящих сцен, а их катализатор. Если бы генерал Пралинский во всю жизнь не пил ни шампанского, ни водки, он бы пережил те же самые разочарования, только, возможно, в более безобидном и щадящем, пролонгированном режиме, - но сущность этих испытаний была бы та же.

И уж, конечно, рано или поздно они достигли бы своего «патетического момента», который в рассказе естественным образом совпадает с высшей и последней стадией опьянения, когда, вопреки даже последовательному течению событий и эмоций, Ивану Ильичу захотелось плакать, и он вдруг «...снова начинал любить, любить всех, даже Пселдонимова... Ему захотелось вдруг обняться с ними со всеми, забыть все и помириться. Мало того: рассказать им все откровенно (...) «Я откровенностью их дойму. (...) я их покорю неотразимо... и все они будут любить меня, и я выйду со славою!..»

Скоро, запинаясь и брызгая слюной, он громко повел свою патетическую речь:«"- Россия... да, именно Россия... одним словом, вы понимаeme, что я хочу ска-ка-зать... Россия переживает, по моему глубочайшему убеждению, гу-гуманность..." "- Гу-гуманность!" - раздалось на другом конце стола. "- Гу-гу!" "- Тю-тю!.."»

Будучи несколько раз таким хамским и издевательским образом прерван, генерал Пралинский окончательно скисает: « - ... то есть я хочу сказать... что вы меня не любите... А между тем я люблю вас всех... чем я унизил себя? (...) Порфирий, обращаюсь к тебе... Скажи, если я пришел... да... да, на свадьбу, я имел цель. Я хотел нравственно поднять... я хотел, чтоб чувствовали. Я обращаюсь ко всем: очень я унижен в ваших глазах или нет?»

Наконец, эмансипация, как это неизбежно случается, перерастает в революцию. Молодой сотрудник сатирического листка «Головешка», присутствующий между гостями, вредный, амбициозный и не более трезвый, чем генерал Пралинский, вдруг «с сверкающими глазами стал отвечать от лица всего общества."- Да-с! - закричал он громовым голосом, - да-с, вы унизили себя, да-с, вы... ретро-град!.. Вы пришли ломаться и искать популярности. Да, вы пришли, чтоб похвалиться гуманностью! Вы помешали всеобщему веселью. Вы пили шампанское и не сообразили, что оно слишком дорого для чиновника с десятью рублями в месяц жалованья, и я подозреваю, что вы один из тех начальников, которые лакомы до молоденьких жен своих подчиненных!.. Да, да, да!"»

Буяна, конечно, вытолкали, но Иван Ильич был безутешен: " - Hem, нет!.. я уничтожен... я пришел... я хотел, так сказать, крестить. И вот за все, за все!»

От избытка чувств и промилле Иван Ильич сначала ударил лицом в бланманже, которое перед ним было заботливо поставлено, а потом рухнул под стол - и захрапел. «Это, - говорит Достоевский, словно желая вызвать милость к падшим, - бывает с непьющими, когда они случайно напьются. До... последнего мгновенья сохраняют они сознание и потом вдруг падают как подкошенные».

Закончилось тем, что генерала Пралинского, в виду его тяжкого состояния и слишком позднего времени хозяева оставили у себя, а поскольку приличного для такой важной особы места в доме регистратора Пселдонимова не было, то его положили на брачном ложе (а молодым постлали на стульях).

На этой постели, предназначенной «для райских наслаждений», генерал, с которым случилось ужасное расстройство желудка, пережил прямо адские муки, и до самого утра мать жениха, простая русская баба, утешала его, как ребенка, накладывала ему компрессы и выносила за ним тазики: луч света в темном царстве; тот самый народ, которому генерал хотел обозначить нравственную цель и показать пример гугуманизма.

\section{7. ИНСТАГРАМ И СТО ГРАММ}

Это еще не вся история. Эпилог смотрите у самого Достоевского (вообще, всегда лучше, конечно, читать первоисточники, чем чьи-либо конспекты). Но основную часть сюжета мы в глав- 
ных динамических и психологических пунктах исчерпали, и уже можем заключить, что Иван Ильич опростоволосился потому, что на самом деле народа не любил и не знал, а только искал любви себе, то есть хотел, чтобы его любили.

Сегодня на слуху слово «популизм». Генерал Пралинский - типичный популист: жажда дешевой популярности подобно хмелю застила ему глаза и лишила его такта и бдительности. Достоевский, помимо остального, показывает, что популизм - всего лишь особая форма тщеславия, ханжества и чванства.

Популистов сегодня очень много развелось; такта и бдительности не хватает многим политикам. Танцующего президента мы взяли только как апофеоз этого явления. Очевидно, что народные комментарии на эти танцы, размещенные в свое время в ю-туб, гораздо чувствительнее тех хлебных шариков, которыми гости бросали в Ивана Ильича, - а есть там шарики и вовсе уже не хлебные...Не сомневаюсь, что и президенту были знамения, чтобы он не ходил на ту дискотеку, но он ими пренебрег...

Когда я смотрел, как танцует президент, я испытывал неловкость и за него, и за себя; у меня было такое чувство, словно я не смотрю, а подсматриваю и словно становлюсь участником какого-то кощунства. А потом я осознал, что отчасти в этом и камера виновата: заметьте, что танцующего президента снимают только со спины. Он ли отворачивается от камеры, или операторы обходят его с тыла - не важно: важно, что все, включая танцора, чувствуют и понимают, что президент не на месте. Власть и свобода - далеко не одно и то же. Президент, в частности, не располагает свободой танцевать где и как хочет.

Такие хождения в народ никуда не ведут. Вспомните и другого президента, президента уже не существующего государства, этого простодушного «человека толпы», который повадился разъяснять государственную политику случайным прохожим на улице.

Власть - это не интересная работа, а тяжкий труд. Кто думает иначе, тот власти не достоин.

Власть сакральна, и мне представляется профанацией даже привычка некоторых ее представителей пользоваться соцсетями. Власти не стоит злоупотреблять открытостью. Я называю это властным эксгибиционизмом.

Словом, дистанция необходима. Ей-богу, иногда мне кажется, что любой начальник просто обязан быть немного «вещью в себе», то есть, самодуром; самодурство - атрибут харизмы.

Конечно, как я уже сказал, исходные декларации Ивана Ильича благородны. Не зря ведь Кондратий Рылеев писал задолго до Достоевского: «...имеющий намерение возбудить к себе страх над бедными только рабами владычествовать будет, и потому великих дел от подданных своих ожидать себе не может. Имеющий же дарование возбудить к себе любовь будет управлять сердцами своих подданных (...) Власть имущий тем паче превышает, чем более равняет себя с ними».

Прекрасно. Я тоже в это верю. Но давайте, ваше превосходительство, отличать гуманизм от гугуманизма и не пить с подданными шампанского, во всяком случае за их счет. И уж боже вас упаси выпить после шампанского водки.

\title{
A CORNY JOKE
}

\author{
I.S. Hugaev
}

Ph.D., a leading researcher of the Integrated Research Department of Vladikavkaz Scientific Center RAS

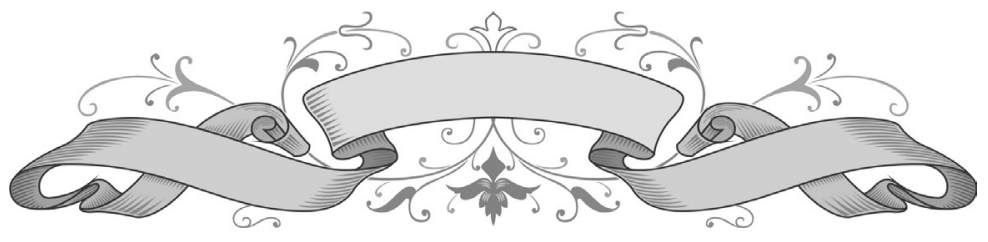

